
Multidisciplinary
SCIENTIFIC JOURNAL

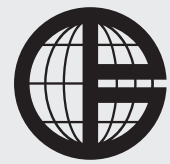
Multidisciplinarni
OF MARITIME RESEARCH

\title{
Comparative Analysis of the Concessioning Model of Maritime Domains in the Territory of Both the European Union and the Republic of Croatia with a Focus on the Seaports
}

\author{
Antonija Mišura ${ }^{1}$, Renato Oblak ${ }^{2}$, Filip Bojić ${ }^{1}$, Sonja Vizjak ${ }^{3}$ \\ ${ }^{1}$ University of Split, Faculty of Maritime Studies, Ruđera Boškovića 37, 21220 Split, e-mail: amisura@pfst.hr; fbojic@pfst.hr \\ ${ }^{2}$ University of Rijeka, Faculty of Maritime Studies, Studentska 2, 51000 Rijeka, e-mail: renato.oblak@ri.htnet.hr \\ ${ }^{3}$ Attorney-at-law Ph.D. Sonja Vizjak, Šojska 25d, 51221 Kostrena, e-mail: sonjavizjak1@gmail.com
}

\section{ABSTRACT}

The maritime domain is the common domain of special interest, so it has special protection of the state and certain rules of use. One of the models of the maritime domains management in the territory of the Republic of Croatia is the concessioning system, and it is based on various legislation and bylaws that determine the type of concessions, the method of determining the concession fee and the methods and criteria for awarding the concession. The concessions' management is primarily related to the economic use of maritime domains. The aim of this article is to carry out a comparative analysis of the concessioning model of maritime domains in the territory of the Republic of Croatia and the European Union with a focus on the seaports. For the purpose of economic use, today's models of the maritime domains' concessioning in the territory of the European Union are not unambiguous, as they depend on the tradition and historical development of the system even though they are subject to constant changes. The carried out research points to the need of developing the system in the Republic of Croatia with the obligation to harmonising legislation, strengthening criteria within the system and increasing the degree of openness of the market in accordance with the European acquis.

\section{ARTICLE INFO}

Review article

Received 3 May 2020

Accepted 25 May 2020

\section{Key words:}

Concessioning system

Seaports

Republic of Croatia

European Union

\section{Introduction}

The maritime domain is the common domain of special interest, so it has a special protection of the state and certain rules of use, and an essential part of the maritime domain are the seaports. For the Republic of Croatia, the maritime domain is generally a domain under the special protection of the state and is used under the conditions and in the manner prescribed by the laws. It consists of inland sea waters and territorial sea, seashore and seabed and underground [17]. The maritime domain belongs to all people as a common good and in this sense it is inalienable, cannot be an object of acquisition of property rights or the other real rights and cannot be in transport [17]. Maritime domain is a resource to be accessed with particular care in order to reduce the level of risk, and this is only possible by upgrading and developing the system and learning [31]. One of the models of maritime domain management in the Republic of Croatia is the concessioning system. A concession is a law which partially or com- pletely excludes part of the maritime domain from general use and it is given to special use or economic use by legal and natural persons, in accordance with spatial plans [32]. Various legal frameworks define the concessioning system, the way the concessions are awarded and the determination of fees under this system. The legal backbone is the Law on Maritime Domains and Seaports and the Law on Concession. The last amendments to the Law on Concessions on Maritime Domains give greater power to the Ministry of Finance, because for good long-term management, an important assessment of the actual value of the concession is a precondition for a long-term assessment of economic sizes [18]. It is aimed at simplifying the procedure subject to an increased level of efficiency and introduction of quality criteria when selecting the concessionaire [10].

The importance of maritime domains and seaports in all maritime countries of the European Union is evident. The governance is largely under the state, but the management mode is not equivalent even though it is similar. 
Today's form depends largely on tradition and historical development of the system. In relation to Croatia, other maritime countries of the European Union have a much longer tradition of the concessioning system of maritime domains, but continue to work systematically to improve existing and develop new models of management of this important resource with a view to achieving as much social and economic benefit as possible for all stakeholders.

Croatia has been a member of the European Union since 2013 and models of the maritime domains and ports' concessioning in the Republic of Croatia and the European Union are compared with this starting point. For the purpose of this research, the hypothesis is that Croatia does not deviate significantly from other maritime countries of the European Union in relation to the management of maritime domains and seaports through the concessioning system.

\section{Overview of Previous Research}

The concessioning of maritime domains and seaports is a significant area of the research in the maritime countries of the European Union, from different aspects, so Ferrari et al. (2015) carried out a survey of the efficiency of the concessioning over maritime domains and they concluded that new technologies are causing an increased need for privatisation of port activities or even complete port areas with the necessary transparency and a common regulatory approach [5]. Ferrari and Basta (2009) concluded by exploring the impact of liberalisation on Italian seaports that good results can only be achieved through the functioning of the whole system, and stress the need to limit the level of concession fees, which may be the beginning of the homogenisation of the system within the European Union [4]. Cruz and Marques (2012) analysed the risk-sharing when concluding concession contracts in the field of ports of Portugal, from which they concluded that the concessionaire and the port authority of the contracts in question are closely bound in the long term, which also raises some problems with the efficiency of the seaports management [3]. According to Paroli et al. (2012) the key point of a good port management is precisely the allocation of activities to the private sector through the concessioning system, and they also investigated in the field of seaports in Italy [25]. Palazón et al. (2018) concluded through the beaches management, as a maritime domain, through concessions in Spain that sustainable governance is necessary, which is often lacking due to disharmony in the implementation of regulations at local and state level [22]. Pallis and Vaggelas (2005) explore this issue in Greece, in relation to the required liberalisation by the European Union and conclude that ambiguity is almost impossible due to the great influence of tradition [23]. The efficiency of ports depends on a number of factors, and one of the more important is the concessioning system. Polyzos and Niavis (2013) examined the effectiveness of the ports in the Mediterranean due to the rapid development of the port industry in the seaports in the Mediterranean and came to the realization that all performance needed to be improved in order to grow the efficiency of the whole system [6].

Scientific literature demonstrates the strong interest of all maritime countries in the territory of the European Union in relation to the issue of the maritime domain and seaport management, and within this framework the concessioning system is included. Scientists and experts in the Republic of Croatia do not lag behind these trends. Consequently, Bolanča (2015) has explored the historical development of the legal status of maritime domains in the territory of the Republic of Croatia and future legal solutions especially on properties located on the maritime domain and concluded that changes in legal frameworks are necessary [2]. Roso (2001) also concluded that the amending laws are necessary by making the general (maritime) domain decision of the representative body of citizens with the obligation to make concessions over maritime domains economical, orderly and lawful in its entirety [26]. Vojković and Zovko (2018) surveyed indicate the introduction of restrictions on the general use of maritime domains due to the frequent violations of legal rights by concessionaires, all due to the difficult determination of their rights within the law [30]. Mezak et al. (2019) analyse legislation relating to concessioning in maritime areas and indicate that certain legal provisions must be adapted in order to improve the quality of the concessioning procedure, while highlighting the obligation to determine the actual value of the concession fee as precisely as necessary in preparing the feasibility study [18]. The concession implies the possibility to use the general or public property which entails the business activity of the property concerned. This is confirmed by Jugović (2011) with his exploring the impact of a new classification of certain county ports open to the public transport, where he concludes that this ensures commercial use leading to a more settled system and the preservation of natural resources [7].

According to Notteboom (2007), the concession in the territory of the European Union was accepted as a means of fair competition in the services provision in the port area [21]. The need to compare the way the concessionings are carried out in the European Union arises from the previous one. Thus, Jugović and Schiozzi (2013) compared the concessioning system over seaports in Croatia and Italy and concluded that in Italy the concept of maritime domains is clearly defined, which implies a simpler concessioning procedure while Croatia still lacks a concrete strategy for managing maritime domains and thus seaports [8]. Nakic (2016) extended the comparison to Portugal, the Netherlands, Spain and France and concluded that only the Netherlands deviates from all, because it does not have a concept of maritime domain at all, whilst in the other countries a maritime domain is a state property, which is used through concessions, with differences of definition as a public or common property [20]. 
The changes and development of the new technologies open up new areas of application of different concessioning models of maritime domainss and ports in the European Union and the Republic of Croatia. Since 2013, the Republic of Croatia has been an equal member of the European Union and it is therefore constantly compared to the other member states, especially with maritime countries in the surroundings. The comparison not only detects differences between them, but learns from the concrete examples and creates a basis for progress.

\section{The Analysis of the Model for Awarding the Concessions on Maritime Domains in Comparable Countries in the Surroundings (The European Union Members in the Mediterranean)}

With respect to Croatia, other maritime Member States of the European Union have a much longer tradition of open market and concessioning system of maritime domains and they are systematically working to develop new management models of this important resource with a view to achieving as much social and economic benefit as possible for all stakeholders. Approaches vary from country to country and depend on the infrastructure, economic and political specificities that prevail in this area. National port management means state-by-state governance. The state's form of governance is present in the Republic of Croatia, but also in Italy (except the ports of Genoa, Trieste, Venice and Livorno) and in certain French ports. The most pronounced disadvantage of this model is inflexibility, political interference and burden of the public financial system while the benefits are social benefits, strengthening the connection of seaports to the hinterland, the freedom to choose a location for the construction of new ports and facilitate the resolution of property-legal issues. The described model of the seaport management is very similar to the model of the city or region governance, although this model is more elastic and requires greater engagement of local policy. County port administrations in the Republic of Croatia belong to this model of sea port management. The autonomous port management model implies direct involvement of the stakeholders. This model is increasingly represented and can be organized in a variety of ways. The two variants are most represented where in the first variant the beneficiaries directly participate in the management through the Community governing Council formed by representatives of the concessionaire, Chamber of commerce, representatives of the city and the port workers, while in the second variant an association is created between the company that manages the port area and the users themselves [19]. Due to the growth of the economic importance of maritime domains and port areas, the need to invest in large infrastructure projects for which there is often insufficient public money and a model of public-private partnership is also growing. To achieve a equal relationship between the public and pri- vate sectors, both sides must meet the set expectations. A special exception is privately owned seaports where the main motive is the financial looseness of the public sector, because in this model the private sector manages the port and invests in its infrastructure, superstructure and modern mechanisation [9]. A survey published in 2016 by the European Sea Ports Organisation (ESPO) shows that $87 \%$ of publicly managed ports, $7 \%$ in public-private arrangement and only $6 \%$ of private ports, with $51 \%$ of ports restructuring, bringing management closer to the private sector [27]. It is concluded that the state still has the greatest dominance in the management of maritime goods and ports within the European Union, but the increasing presence of the private sector is evident, so the ESPO report states that the bulk of essential port services are carried out by the private companies. So, for example, you're going to have $88 \%$ of haulage, $65 \%$ mooring, $94 \%$ bunkering, $80 \%$ cargo handling on board, $88 \%$ logistics services, $81 \%$ storage, $100 \%$ barrage transport $100 \%$ executed by private companies [27] making the business more efficient with a quick response to new trends.

The leving of the port business to the private sector is carried out in various ways, and the most common way is through the concenssioning system. In more than $50 \%$ of private sector deployment cases, it is through the concessioning system [9].

\section{The Analysis of the Existing State of the Concessioning System in the Republic of Croatia}

The concession of the maritime domain is a very complex issue faced by the countries with a longer tradition of the open market and persistently developing legal models to achieve the best way to manage maritime domains, i.e. port systems [1]. Within Croatian legal theory, some concession theorists define a concession as a special legal institute through which public authority allows a particular entity, a natural or legal, domestic citizen or foreigner, to use or exploit certain propertiess, perform certain works or perform any activity, and some theorists define the concession as a legal instrument by which a state or other public authority allows the concessionaire to exploit some natural property [28]. The most important applicable legislation and bylaws in the Republic of Croatia, which are also the basis for the development of the concessioning system, are as follows:

1. Law on Maritime Domains and Seaports

2. The Law on Concession

3. Maritime Code

4. Regulation on the procedure for granting concessions on maritime domain

The inter-legal links and the importance of a particular provision stem from an understanding of the concepts of the common domain and the maritime domain. Maritime domains, and therefore seaports, according to the Law on 


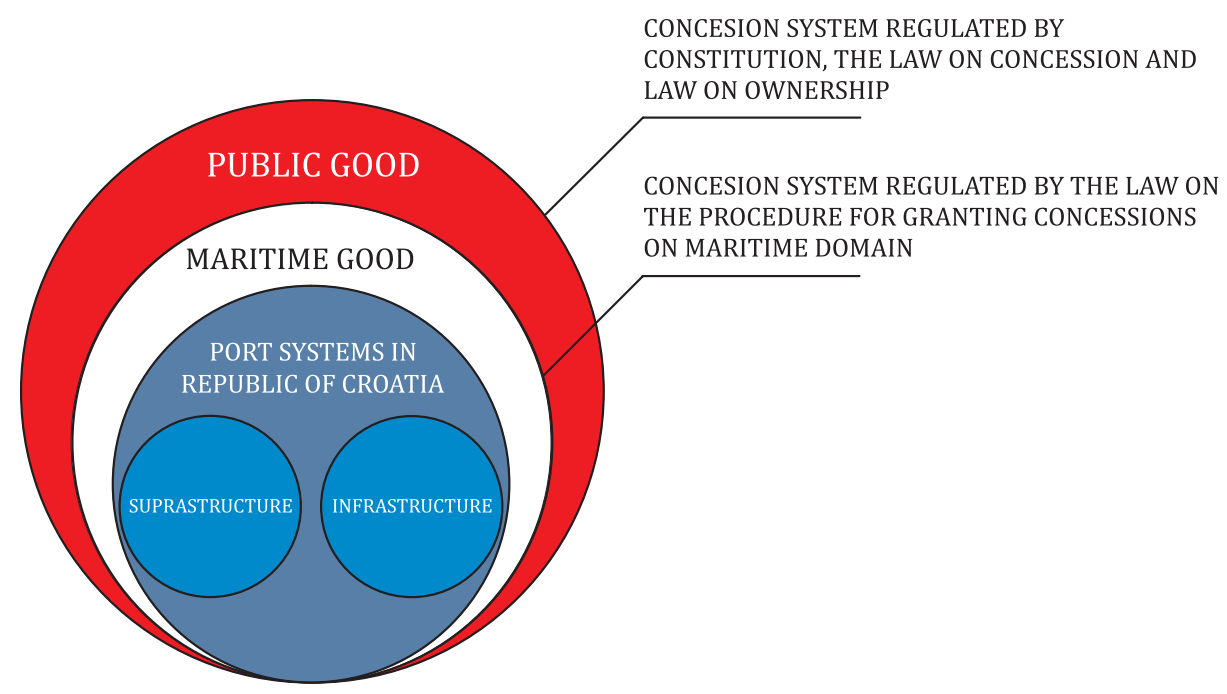

Figure 1 Sort key concepts for the concessioning port systems

Source: Authors

Maritime Goods and Seaports are defined as a common domain of interest to the Republic of Croatia, and according to the Law on Ownership and Other Real Rights the common domain may not be owned by any legal or natural person but in the use of all. The above suggests that the legal concept of the common domain covers a wide range of important resources of the Republic of Croatia, which includes the maritime domains of which the essential component of which are port systems, as shown schematically in Figure 1.

The concept of concessions in the ports of the Republic of Croatia dates back to 1990 with the adoption of the first Law on Concessions, which defines the general legal regulation of concessions. In the creation of the current Law on Concessions, European Union directives have played an important role, whose basic principles are transparency, equal competition and equal treatment, and a significant change is in the criteria for selecting the best offer within which the concept of innovation occurs. In order to achieve an effective choice of a better enterpreneur, it is necessary to define precisely the concepts for the purpose of creating clear criteria and restrictions on free interpretation. The Law on Concessions also provides the possibility of establishing a lien solely for the benefit of financial institutions and the concession contract may be transferred to a third party with the consent of the grantor. With this regulation, the concessionaire can be more flexible in terms of the financial structure when making the study. There is also a novelty - a subcontract by which the concessionaire can entrust the planned services to a smaller extent to a third party, which means a different revenues schedule for the concessionaire, but also the question of its ability to carry out activities that are transferred to a third party. In addition, the provision of Art. 1, Paragraph 2 The Law on Concessions, which eliminates the possibility of applying certain rules of special laws governing concessions other than the umbrella Law on Concessions, i.e. which are not harmonised with that Law [17].

The Law on Maritime Domainss and Seaports in relation to the observed problem shall be carried out by the following:

- provides the competence of the administrative departments in the regional self-government unit responsible for maritime affairs for the determination of the boundaries of maritime domains,

- provides for a procedure for granting the concessions on maritime domain,

- introduces the duty of the grantor to carry out previous and preparatory actions for granting the concessions in accordance with the procedures and actions set out in the Law on Concessions,

- introduces the law and duty of participation of the competent ministry in the process of drafting and adopting all documents and acts of spatial planning covering the field of maritime domain,

- regulates the establishment of a county port administration in units of regional self-government, which may have outposts,

- entitles large cities to establish a city port authority,

- introduces the duty of the county port authority to carry out port activities on its own, and the concession for the performance of port activities is granted only exceptionally and exclusively for the construction and economic use of new sub-construction and superstructure facilities, the reception and leaving of all types of waste from maritime facilities and the supply of waterway facilities by fuel,

- introduces a single port tariff in ports of county and local importance open to public transport that combines port fees and port charges and 
- the issue of conversion on the maritime domains and others [32].

It is important to point out that according to the Law on Maritime Domains and Seaports, all buildings and other facilities on the maritime domain belong to the maritime domain itself, which makes it clear that the legal regime presented is based on the following principles:

- that the things are in general use and outside the legal traffic,

- unity of land and building, i.e. uniqueness of the property [1].

The concessioning system is a complex issue with a range of pros and cons. Certain advantages of concessions in the port sector are:

- better and more efficient management of port operations by private operators,

- abolition of monopolies and the development of competitiveness among private operators,

- investing private capital in socially justified projects and freeing up state funds for other projects,

- creating a new source of revenue for port administration and

- risk transfer for the construction, financing and use of the facility to the private sector [19].

As disadvantages related to concession contracts can be stated:

- the need to continue state regulation and supervision,

- the system requires a legal framework that allows the transfer of ownership rights to the private sector,

- sometimes concessionaire offers are based on unrealistic financial projections, so the viability of concession contracts is called into question and

- the risk that the concessionaire will not properly maintain the facilities under the concession, returning them to the state in poor condition, or the risk that the concessionaire and the port authority disagree on the justification of the investments [1].

Since the general domain or port systems cannot be exercised, the only way to manage that resource is through the concessioning system. Therefore, six Croatian state ports have contracts with concessionaires for the performance of port and commercial activities, so the Port Authority of Rijeka has 83 active concessionaires and the primary concession is owned by the company Luka Rijeka d.d. [13], Port Authority of Zadar has a total of 49 active concessionaires and the primary concession is owned by the company Luka Zadar d.d. [16], the Port Authority of Šibenik has 21 active concessionaires and the primary concession is owned by the company Luka Šibenik d.d. [14], Port Authority of Split has 92 active concessionaires and The Port of Split d.d. is the primary concessionaire [15], the Port Authority of Ploče has 21 active concessions and the primary concession is owned by Luka Ploče d.d. [12] while the Port Authority of Dubrovnik has 21 active concessionaire and the primary concession is the company Luka Dubrovnik d.d. [11].

\subsection{Types of Concessions}

According to Croatian law, there are three types of concessions:

1. concessions for the economic use of the general or other domain,

2. concessions for public works and

3. concessions for public services.

The grantors of concessions are the Croatian Parliament, the Government of the Republic of Croatia, the authorities of the local and regional self-government units and other legal entities (special regulations authorized to grant concessions) [32]. However, the basic legal basis for the concession of the port area is the Maritime Domain and Seaports Act, which is considered lex specialis in relation to the Law on Concessions, which was lex generalis [1].

In the Republic of Croatia, maritime domains and ports are managed through a concessioning system, and are divided under the Law on Maritime Domain and Seaports (Art. 66) to:

1. concession for the performance of port activities, which does not require the exclusive use of existing or the construction of new buildings and other substructure and superstructure facilities in the port area,

2. concessions for the pursuit of other economic activities referred to in Article 65, Paragraph 1, point 5 of this Law, which do not require the exclusive use of existing or construction of new buildings and other substructure and superstructure facilities in the port area,

3. concession for the performance of port activities, requiring the use of existing and/or construction of new buildings and other substructure and superstructure facilities in the port area and

4. concessions for the performance of other economic activities requiring the use of existing and/or construction of new buildings and other substructure and superstructure facilities in the port area [32].

The Maritime Goods and Seaports Act also prescribes port activities which may be carried out in ports open to public transport, relating to: mooring and unboundrthing of ships, yachts, fishing and other vessels and floating objects, boarding, disembarkation, transhipment, transfer and storage of goods and other materials, the boarding and disembarkation of passengers and vehicles and other economic activities which are in the immediate aftermath of economic, transport or technological connection [32]. These activities may be carried out by legal or natural persons using existing substruc city and superstrucment and build upbuilding facilities and sub-construction only on the basis of the awarded concession by the port administration through tendering [32]. 


\subsection{Concession Award Criteria}

In the Republic of Croatia, the Ministry of the Sea, Transport and Infrastructure is responsible for concessions on the maritime domain or body under its jurisdiction such as port administrations in the case of ports open to the public transport. The concession can last from 5 to 99 years, depending on the construction or use of facilities for the county or the state importance, and the time of depreciation. For the entire period of the contract, the concessionaire shall pay the concession provider a fee consisting of a fixed and variable part the size of which depends on the coverage of the project itself. The award of concessions for the economic use of maritime goods precedes the public collection of tenders. After the expiry of the tender period for the award of concessions in ports open to public transport published in the Official Gazette, the expert body shall start evaluating valid tenders according to the following criteria:

- offered height of the fixed part of the concession fee $30 \%$,

- offered amount of the variable part of the concession fee $30 \%$ and

- the amount of total investment offered according to the Economic Justification Study, which also includes technical and technological equipment for the execution of the plan $40 \%$ [29].

Each element of the tender shall be valued separately, and the sum of the total assessment by criteria cannot be more than 1.00 , with the variable part of the concession fee calculated in absolute amount according to the total revenues shown from the economic justification study, and for the duration of the concession [29].

In some cases, additional criteria may be introduced for validation of incoming tenders, but they must be determined when deciding to publicly collect tenders. In the case of the concession type with the required construction of facilities and the acquisition of mechanization, most often in the concession tender itself, the threshold of compensation is lowered with the obligation of major investments in development, knowledge of the concessionaire in the management and expansion of the business. According to the Regulation, the length of the concession duration is also an essential element of validation of the offer of a potential concessionaire.

\subsection{Concession Fee Level Determination Models}

Doing business in maritime domains and within port areas are left to the private sector through a concessioning system in order to achieve maximum efficiency and flexibility. This right shall be acquired by a contract whose primary function is the costs transfer to the private sector. The primary function of a concession contract is to transfer investment costs from the state to the private sector. The contract defines the period of the duration of the concession and the level of the concession fee.
The concession fee depends on the type of concession, the amount of investment in the eventual construction of facilities, the coverage of the port area, the procurement of mechanization, the environmental impact, the development of the service, the employment of the professional staff, etc. and the nature and quantity of work the concessionaire will carry out i.e. height is determined by the profitability of the economic use of maritime domain which is demonstrated by the study of economic justification, the estimated degree of endangerment of nature, the human environment and human health, and the protection of the interests and safety of the Republic of Croatia [32].

The concession fee for the economic use of the maritime domain consists of:

- the fixed part to be paid from the heading of the total number of square metres of the port area and

- the variable part to be paid depending on the volume of activity, the significance of the activities for the technical and technological unity of the port, and the impact on the port traffic [29].

In the case of concession fees given for the special use of maritime goods, the same shall be determined in a symbolic amount, while in the case of a concession for the infrastructure construction (water, sewage, energy and telephone) the fee is determined as for the economic use of the maritime domain [32].

In ports open to the public transport, the concessionaire charges its services through the port fee system, the maximum amount of which is prescribed by the port authority. The size of the fee paid by the concession provider for the economic use of the port area is an important segment of business for both parties, but also an important factor when awarding a concession, which completes the tender documents with other criteria, and this is a precondition for the achievement of the concession itself.

\section{The Examples of Concessions on the Maritime Domain in Comparable Countries in the Surroundings (Members of the European Union in the Mediterranean) and the Republic of Croatia}

All maritime countries of the European Union have special care for the maritime domain, although each country has its own specificities in accordance with national legislation and tradition. In the territory of the European Union, maritime domains are generally managed through a concessioning system. Most concessions are awarded through public tendering to a tender which contains certain criteria. The general criteria in the European Union are experience with the aim of eliminating incompetent concessionaires, financial stability and guarantees from tenderers. In addition, the technical part of the tender depends on the subject of the concession is also important, but it demonstrates the ability to perform a specific project and may contain a detailed investment plan, project timings and stages, various 
designs, employment factor, marketing plan and environmental plan [21]. The common maritime countries in surroundings are defined as a public good by maritime good, but governed in different ways.

The specificity of the concessioning system in Spain, irrespective of the subject matter of concessioning, is the registration of acquired right in the land register and the maximum duration of the contract up to 30 years [20]. Spain generates the most significant revenues from tourism, and consequently puts the emphasis on beach concessions where the basic criteria are areas and fees provided for compliance with the environment and long-term sustainability, even though not all beaches have the same treatment [22]. A concrete example of the concessioning system in Spain is the tender for a container terminal in the port of Barcelona. The analysis of this tender concludes that it was addressed exclusively to companies with years of experience in managing a terminal that manipulates more than 500,000 TEU i.e. companies that are in a joint venture with at least one partner with such experience, which also holds a minimum 25 percent stake in a company that competes for a future concessionaire.

In Greece, more specifically in the port of Piraeus, there was a similar situation to that of the container terminal in Barcelona, because one of the basic criteria of the tender is the experience of handling one million TEU per year [24].

Analysing the example of a container terminal in Genoa it can be concluded that one of the most important criteria of the Italian concessioning system of maritime domain is the level of compensation, which consists of a fixed and variable part, which can be changed every two years and depends on the investment of the concessionaire in infrastructure. Consequently, it is clear the importance of the concessionaire's investment criteria [25].

The first concession of the maritime domain in Portugal was in Lisbon, with a long-term contract which, with significant investment by the concessionaire, could be extended [3]. The criterion for extending the contract is also to increase the existing capacities. Analysing concessions in nine ports in Portugal as the most important criterion imposes the level of investment by the concessionaire, as the duration of the contract depends on it and the aim is to align public and private interests in this way [3].

The criteria for concessioning, in addition, are investment in multimodal transport, development of competition within the same port as well as extension and expansion of the concession in the event of a successful business.

It can be concluded that there is no single model, even in the case of generally prescribed equitable guidelines as the European Union has, although the concessioning system has become the dominant way of managing European maritime domains and ports with different governance variants. In order to achieve a long-term successful system, it is necessary to define development policy as a quality basis for the creation of new models and the devel- opment of existing management models through a concessioning system.

Although the Law on Maritime Domains and Seaports prescribes the types of economic use of ports and activities through the concessioning system, and the Regulation itself is the way of awarding concessions, it cannot be concluded that in the Republic of Croatia the system has been fully implemented. This is primarily due to non-compliances between different legal provisions, which is why private capital investments are lacking and therefore the expected concession revenues. However, in addition to these shortcomings, there are positive trends in the development of port systems achieved by different models of concessioning system, which is evident from certain examples in ports of particular importance to the Republic of Croatia. Significant port projects recently, which are directly correlated with the concessioning system, have been in Rijeka, Split and Zadar.

An example of a concessioning model with the characteristics of a public-private partnership is the 2014 project in the port of Rijeka. At that point, the port of Rijeka began a project to build a container terminal on Zagreb pier, whose development was foreseen in two stages through the tender. The first phase involves the construction of a 400-metre (m) long coastal wall funded by the grantor, while within the first phase the construction of the suprastructure and the installation of mechanization will be financed by the future concessionaire. Two years after the end of the first phase, the second phase, which includes the construction of an additional $280 \mathrm{~m}$ coastal wall funded by the concessionaire, must be completed. The model of the concessioning with an estimated value of HRK 2,268,800,000 with a 30-year period and an expected turnover of 350,000 TEU per year has all the characteristics of a public-private partnership. In addition to these criteria, additional criteria are earlier experience in business and financial guarantees.

The described example is quite different from the project of building two external berths for the consent of the cruise ship in the port of Split. In fact, in 2002, the port of Split was the first port of Croatia to be opened. Since 2016, it has recorded 20,616 cruise ship passengers, and in 2016 that figure exceeded 250,000 visitors. This significant increase in passengers from cruise ships has provided a project to build additional berths for cruise ships. The $265 \mathrm{~m}$ and $245 \mathrm{~m}$ berths were completed in 2017 and the whole project was financed by the public money (European Banks, Republic of Croatia and Port Authority of Split), while the performance of port services was handed over to concessionaires who obtained their rights through tenders. A very important project is the construction of the port Gaženica in Zadar. The mentioned port is a complete terminal, which includes a passenger terminal for domestic and international ro-ro traffic and the traffic of cruise ships, on concessional management. Construction itself took place in three stages and was completed in 2017 when the tender for the concession was announced with an estimated value of HRK 113,183,146.72 
for a period of 20 years. The concession provider has built the terminal and the rest of the infrastructure needed to operate while the concessionaire's obligation is to maintain the same and to procure a pedestrian boarding bridge if the need for this investment arises.

The analysed capital projects highlight the desire for progress, increasing capacity and improving service, and they are certainly an indication of positive trends in the technical and technological progress of our ports. However, further development and more efficient use of existing infrastructure, in the form of service improvements, can only be realized by harmonising legislation with mandatory adaptation to market requirements. This would lay the groundwork for a more efficient implementation of the concessioning system in the maritime domain and port area.

Analysing examples of the concessioning system of maritime domains in the surrounding countries of the European Union (Mediterranean) constructs a realistic picture of the system's performance. Each example points to certain advantages and weaknesses of the system and creates prerequisites for progress and improvement. Croatia, as a country with a significant share of maritime domains but also with significantly less experience of operating on the free market, only by the comparison of the named system with the same one in the surrounding maritime countires can clearly define its position and develop its system in the quality way. Differences and similarities within the system are presented in Table 1.

Analysing Table 1 there is a conclusion that Croatia does not define the maritime domain in the same way as other maritime countries in its surroundings. All countries categorise maritime domain as a public domain and Croatia as a common domain. The same basic principle is used to determine concession fees while maritime countries in the surroundings have a wider range of criteria, which certainly results from longer-term experience.

There is no unified way of awarding concessions on the maritime domains in the European Union, despite uniform legal principles based on transparency, equal competition and equal treatment. These differences are not only visible between different EU countries, but also between individual ports within the same legal systems. However, if we were to make a general presentation of the evaluation process of the award of concessions in the European Union and the

Table 1 Comparison of the concessioning system of countries in the surroundings and the Republic of Croatia on the given examples

\begin{tabular}{|l|l|l|}
\hline $\begin{array}{c}\text { Comparison of } \\
\text { concession schemes on } \\
\text { the examples }\end{array}$ & \multicolumn{1}{c|}{$\begin{array}{c}\text { MEDITERRANEAN } \\
\text { (Italy, Greece, Spain, Portugal) }\end{array}$} & REPUBLIC OF CROATIA \\
\hline $\begin{array}{l}\text { Categorisation of } \\
\text { maritime domain }\end{array}$ & public domain & common domain \\
\hline Concessioning criteria & $\begin{array}{l}\text { evidence of financial stability, guarantees, level of concession } \\
\text { fee, years of experience, investment in multimodal transport, } \\
\text { development of competition within the same port, extension and } \\
\text { expansion of concessions depending on the level of investment }\end{array}$ & $\begin{array}{l}\text { evidence of financial stability, } \\
\text { guantees, the level of concession fee, } \\
\text { the level of investment, experience }\end{array}$ \\
\hline $\begin{array}{l}\text { Determining the } \\
\text { concession fee }\end{array}$ & fixed part + variable part & fixed part + variable part \\
\hline Specifics & Spain - registration of concession law in the land register & \\
\hline
\end{tabular}

Source: Author

Table 2 General presentation of the evaluation process of the concession award in the European Union and the Republic of Croatia

\begin{tabular}{|l|c|c|}
\hline \multicolumn{1}{|c|}{ Common principles } & EU (Italy, Greece, Spain, Portugal) & REPUBLIC OF CROATIA \\
\hline Use of concessioning system & Yes & Yes \\
\hline Financing infrastructure construction & Private capital & 30 \\
\hline Average duration of concessions (in years) & 40 & Yes \\
\hline Public offer collection & Yes & Yes \\
\hline Experience in business & Yes & Priority \\
\hline Fee level & Lower priority & Lower priority \\
\hline $\begin{array}{l}\text { Investment in infrastructure and development } \\
\text { (multimodal, technological, ...) }\end{array}$ & Priority & No \\
\hline $\begin{array}{l}\text { Fostering a successful business (extension of the } \\
\text { concession, increasing the scope of the concession, ...) }\end{array}$ & Yes & \\
\hline
\end{tabular}

Source: Authors 
Republic of Croatia (Table 2), we would notice significant differences particularly in the way of financing infrastructure construction and flexibility in the award of concessions, but also in the cooperation with the concessionaire.

Table 2 shows the differences between the other maritime countries of the European Union and the Republic of Croatia in the principles of the concessioning system. In the Republic of Croatia, public capital financing is still present and investment in infrastructure by concessionaires is a less priority factor, while in other European Union maritime countries investment in infrastructure is a priority and is very much financed by the private capital concessionaires. The Republic of Croatia, as well as the other maritime countries in the European Union surroundings, uses the method of public tendering to tenders with the emphasis on the necessary experience in business, but still does not have elaborate the models of encouraging the successful business within the system itself.

This research concludes that Croatia deviates from this problem in relation to the countries in its surroundings, but not so significantly given the time period of existence of the entire system, although progress and growth is necessary through harmonisation of legal provisions and monitoring of current trends.

\section{Conclusion}

The maritime domain is the common domain under the special protection of the state. The Republic of Croatia categorises the maritime domain as a common domain, which means that it is for the use of all but without the ownership of a public, legal or natural persons while maritime countries in the surroundings on the territory of the European Union or the Mediterranean, maritime domain is categorised as a public good owned by the state or other public legal entity and as such in the use of all. There is a strong interest of the state in the management and protection of maritime domains in both categories.

The Republic of Croatia manages the maritime domains with a focus on the port system mainly through a concessioning system on the grounds that maritime domains cannot be exercised. A concession is a right which excludes part of the maritime domain from general use and gives use to legal and natural persons under the contract. This system aims to find the optimal way to manage the maritime domains and port system. The basis of the development of the system is the legal frameworks and regulations, and the most important are the Law on Maritime Goods and Seaports and the Law on Concessions. The legislation determines the type of concessions, the method of determining the concession fee, and the methods and criteria for awarding the concession.

The issue of concessions is very complex and it is also faced by European Union countries with a much longer tradition of the open market. While the European Union means maximum market liberalisation, transparency and equal access, there is a great deal of influence in tradition, which impedes ambiguity. The European Union's maritime countries are at the forefront of the concessioning system as a model for managing maritime domains and ports with increasing private sector representation. Technological changes, development of intermodal transport, globalisation of port operations, deregulation and institutional change, the growth of private capital and the strengthening of the role of strategy in governance are changes that, through strengthening and changing criteria in the concessioning system, affect the overall system.

The carried out research points to the need to develop a concessioning system in the territory of the Republic of Croatia, given the proven lag in the determination of concession criteria in relation to European practices, although there is no significant deviation in the management of the maritime domains management system itself. By comparing with maritime countries in the surroundings, it is evident that there is a scope for progress and long-term development that should be preceded by the coherence of laws and bylaws in order to avoid the possibility of different interpretations and abuses of acquired rights. A thorough, rapid and legally standardized change to the Maritime Goods and Seaports Act is necessary, but also to maintain its umbrella status in application. Due to the sub-normality of legal standards, which are supposed to regulate the essential segments of the concessioning system at seaports, and due to insufficiently articulated port policy, the full potential of management through concessions is not yet exploited. Legal uncertainty and inconsistency in the objectives' development of port systems do not contribute to attracting investors and major projects are missing out. The fact is that in the most Croatian ports the majority of services are carried out by concessionaires, but it is also easy to notice that the equipment of the port and the construction of the facility almost everywhere is financed by public money. Investments in the port should be left to the private sector at least in part, what is a practice in most European ports.

In order to achieve this, the objectives' development of the port policy should be established and legislation regarding the issue of maritime domains and seaports should be harmonised. It can be concluded that the right model of port system management has yet to be found in order to create the basis for more flexible operations, which would bring greater investor involvement and therefore really achieve the full purpose of the port concessioning system.

\section{References}

[1] Batur, T. (2010). "Pravni status morskih luka i lučka politika u Republici Hrvatskoj", Zbornik radova Pravnog fakulteta u Splitu, Vol. 47, No. 3, pp. 677-692.

[2] Bolanča, D. (2015). "Problem stvarnih prava na pomorskom dobru (bitne novine hrvatskoga pomorskog zakonodavstva)", Poredbeno pomorsko pravo, Vol. 54, No. 169, pp. 327-358. 
[3] Cruz, C.O., Marques, R.C. (2012). "Risk-Sharing in Seaport Terminal Concessions", Transport Reviews, Vol. 32, No. 4, pp. 455-47.

[4] Ferrari, C., Basta, M. (2009). "Port concession fees based on the price-cap regulation: A DEA approach", Maritime Economics \& Logistics, Vol. 11, pp. 121-135.

[5] Ferrari, C., Parola, F., Tei, A. (2015). “Governance models and port concessions in Europe: Commonalities, critical issues and policy perspectives", Transport Policy, Vol. 41, pp. 60-67.

[6] Ferrari, C., Polyzos, S., Niavis, S. (2013). "Evaluating port efficiency in the Mediterranean", International Journal of Data Analysis Techniques and Strategies, Vol. 5, No. 1, pp. 84-100.

[7] Jugović, A. (2011). "The need and purpose of a commercial use of the newly classified seaports", Pomorstvo, Vol. 25, No. 2, pp. 271-286.

[8] Jugović, A., Schiozzi, D. (2013). "Comparative analysis of concessions on maritime domain in ports of regional significance in Croatia and Italy", Pomorstvo, Vol. 27, No. 2, pp. 299-312.

[9] Jugović, A. (2012). “Upravljanje morskom lukom”, Rijeka, Pomorski fakultet u Rijeci.

[10] Kovačić, M., Seršić, V., Mladineo, N. (2009). "Managing maritime domain in Croatia - problems of implementing the new concessions act", Pomorstvo, Vol. 23, No. 2, pp. 649-666.

[11] Lučka uprava Dubrovnik, www.portdubrovnik.hr, (Accessed: 20 February 2020).

[12] Lučka uprava Ploče, www.ppa.hr, (Accessed: 20 February 2020).

[13] Lučka uprava Rijeka, www.portauthority.hr, (Accessed: 06 February 2020).

[14] Lučka uprava Šibenik, www.portauthority-sibenik.hr, (Accessed: 12 February 2020).

[15] Lučka uprava Split, www.portsplit.hr, (Accessed: 18 February 2020).

[16] Lučka uprava Zadar, www.port-authority-zadar.hr, (Accessed: 15 February 2020).

[17] Maritime public domain, www.pomorskodobro.com, (Accessed: 5 December 2019).

[18] Mezak, V., Jugović, A., Schiozzi, D., Lapov, F.V. (2019). “Issues in Determining the Real Value of Concession Fees When Granting Concession for Commercial Use of Maritime Domain", Pomorstvo, Vol. 33, No. 2, pp. 255-263.
[19] Munitić, N. (2019). "Management model of the seaports in order to increase their profitability", Faculty of Economics and Business, University of Rijeka, Rijeka.

[20] Nakić, J. (2016). "Pomorsko dobro - opće ili javno dobro?", Zbornik radova Veleučilišta u Šibeniku, No. 1/2, pp. 7-34.

[21] Notteboom, T. (2006). "Concession agreements as port governance tools", Research in Transportation Economics, Vol. 17, No. 1, pp. 437-455.

[22] Palazón, A., López, I., Gilart, V., Bañón, L., Aragonés, L. (2018). "Concessions within the maritime-terrestrial public domain on the beaches of southeastern Spain", Ocean and Coastal Management, Vol. 161, pp. 156-164.

[23] Pallis, A., Vaggelas, G. (2005). "Port Competitiveness and the EU „Port Services“ Directive: the Case of Greek Ports”, Maritime Economics \& Logistics, Vol. 7, pp. 116-140.

[24] Pallis, A.A., Notteboom, T., De Langen, P.W. (2008). “Concession agreements and market entry in the container terminal industry", Maritime Economics and Logistics, Vol. 10, pp. 195-220.

[25] Parola, F., Tei, A., Ferrari, C. (2012). "Managing port concessions: evidence from Italy", Maritime Policy \& Management, Vol. 39, No. 1, pp. 45-61.

[26] Roso. I. (2001). "Upravljanje, održavanje i zaštita pomorskog dobra”, Pomorski zbornik, Vol. 38, pp. 201-214.

[27] The European Sea Ports Organisation, www.espo.be, (Accessed: 2 March 2019).

[28] Tolić, V. (2015). "Koncesija - značenje pojma i povijesni razvoj”, Praktični menadžment, Vol. 6, No. 1, pp. 96-104.

[29] Uredba o postupku davanja koncesijskog odobrenja na pomorskom dobru, Official Gazette 23/04, 101/04, 39/06, 63/08, 125/10, 83/12, 133/12, 63/14, 10/17, Zagreb.

[30] Vojković, G., Zovko, A. (2018). "Notice Boards for Concessions and Concessionary Approvals on the Maritime Domain", Pomorski zbornik, Vol. 54, pp. 129-141.

[31] Vuković, A., Luković, T. (2017). “Maritime domain as public property, the results of strategic planning of national economy development, or?", Dubrovnik International Economic Meeting, Dubrovnik, Croatia.

[32] Zakon o koncesijama, Official Gazette 69/17, Zagreb.

[33] Zakon o pomorskom dobru i morskim lukama, Official Gazette 158/03, 100/04, 141/06, 38/09, 123/11, 56/16, 98/19, Zagreb. 